\title{
LA INOCENCIA DE VERENA: LA QUERELLA POR EL CONTROL DE LA VOZ EN LAS BOSTONIANAS DE HENRY JAMES
}

\author{
DAVID FONTANALS GARCÍA \\ Universitat de Barcelona
}

Las Bostonianas, de Henry James, es una de aquellas piezas literarias cuya naturaleza tiende a la ambigüedad, a la resistencia a las interpretaciones reduccionistas. Hoy en día, la perspectiva de los estudios de género nos permite ir más allá de tales interpretaciones, accediendo al corazón del texto, a aquello que le da coherencia, para poder dar cuenta de sus equívocos más notorios. Así, la primera parte de este artículo está dedicada al análisis del personaje principal de la historia, Verena Tarrant, en cuanto a figura vacía de lo extraordinario y atrapada bajo un sinfín de discursos ideológicos que le dan cuerpo, otorgándole una identidad artificial. En consecuencia, la auténtica Verena queda, paradójicamente, silenciada; su voz, su don, sirve únicamente para expresar los deseos proyectados por los demás personajes. En la segunda parte del artículo, y en un movimiento hacia la esfera de lo público, se lleva a cabo una interpretación alegórica de Verena y de las dinámicas de deseo que giran a su alrededor. Este nuevo nivel de análisis nos lleva a desambiguar el texto, ofreciendo una clave interpretativa del mismo basada en el principio del personaje como representante de una determinada ideología o conjunto de valores. Finalmente, el artículo concluye con la visión de James de una sociedad distópica, vacilante entre dos corrientes ideológicas que están, a su vez, lejos de justificar la realidad a la que aluden.

PALABRAS ClaVe: Henry James, Las Bostonianas, Verena Tarrant, voz, deseo, identidad.

Verena's Innocence: The Dispute Over the Control of the Voice in Henry James' The Bostonians

Henry James' The Bostonians is one of those literary works whose nature tends towards ambiguity and resistance to reductionist interpretations. Today, the gender studies' perspective allows us to surpass such interpretations, and to access the text's core - what holds it together- so as to explain its primary opacities. Thus, the first part of this article is dedicated to the analysis of the story's main character, Verena, as a figure void of the extraordinary and trapped in an unending number of ideological discourses which, in turn, shape her as a constructed identity. Consequently, Verena's self is left silenced; paradoxically, her voice, her gift, is exclusively used to communicate the wishes projected by other characters. The second part of the article, which moves from the private to the public sphere, is an attempt to allegorically interpret Verena and the dynamics of desire which surround her. This second level of analysis will facilitate a reading of the text as less ambiguous, offering an interpretative key based on the notion of character as the spokesperson of a given ideology or set of values. 
Finally, the article concludes with James' vision of a dystopic society, hesitant between two ideological alternatives which are far from justifying the reality to which they refer.

KEY WORDS: Henry James, The Bostonians, Verena Tarrant, voice, desire, identity.

\section{Introducción}

Las Bostonianas de Henry James, publicada por entregas entre 1885 y 1886 en The Century Magazine, es uno de esos ejemplos en el que la evolución y el constante cambio de paradigmas de la crítica literaria conducen a interpretaciones del texto radicalmente opuestas. Como constata Milicent Bell, uno tiene la sensación de que se trata de "one of those works that seems to change shape as times change" (Scheiber, 1992: 235). Esta afirmación, a primera vista perogrullesca, nos lleva a entender la amplia variedad de aproximaciones al texto: desde las que ven en Ransom al prototípico héroe de la historia clásica, quien va en rescate de la damisela en peligro y, por ende, relegan a Olive al papel de "bruja malvada"; ${ }^{1}$ hasta aquellas, lanzadas desde una óptica feminista y más contemporánea, que proponen una lectura de Ransom "as a demonic figure wrapped in 'serpentine imagery' appropriate to one who is the father of lies, and [...] Olive as the representative of a female community aligned with 'a truth that is public and transcendent"' (Auerbach ${ }^{2}$ en Scheiber, 1992: 235). No obstante, ambas perspectivas, aunque basadas en gran medida en el texto, presentan una carencia fundamental, pues no consiguen justificar la ambigüedad subyacente en la obra, imponiendo una lectura eminentemente reduccionista. ${ }^{3}$ Esta ambigüedad, que surge de la necesidad de posicionar al autor tras uno u otro personaje, no es fortuita. La clave para desambiguarla radica en la verdadera protagonista de la historia, sin la cual no habría ni disputa ni tensión que resolver. Así, la naturaleza del personaje de Verena Tarrant nos da la clave interpretativa del texto: Verena, vacía en sí misma, permite a James mostrar todas las fuerzas que están en juego en la sociedad estadounidense de la época, así como formular una dura crítica ora contra el movimiento feminista, portador de los valores progresistas heredados del movimiento abolicionista, ora contra las alternativas conservadoras. Se trata de una sociedad fragmentada y aturdida que vacila entre dos corrientes ideológicas que, a su vez, están lejos de justificar con plenitud la realidad que pretenden permear. Teniendo en cuenta estas premisas, el firme propósito de este artículo es analizar, por un lado, el personaje de Verena en función de las corrientes de deseo que le dan cuerpo, partiendo de la noción

\footnotetext{
${ }^{1}$ Para una exposición sintética y evaluación de las principales aportaciones críticas que defienden esta visión de la obra, véase Fetterley (1978: 101-115).

${ }^{2}$ Cfr. Auerbach, Nina (1998), Communities of Women, New York, Harvard UP.

${ }^{3}$ Cabe decir que no se trata exclusivamente de una evolución de la crítica literaria la que produce divergencias en la consideración del texto, sino que estamos ante una obra que, por su contenido, se presta a un análisis crítico especialmente imbuido de lo político.
} 
de la mujer, o del personaje femenino, como signo portador de un significado potencial. Por otro lado, se llevará a cabo un salto espacial, de la esfera privada a la pública, en un intento de contextualizar la obra de James en un marco de disputa ideológica por el control de las masas estadounidenses de la época. Finalmente, el artículo nos llevará a considerar, a modo de conclusión, la evaluación crítica de James respecto a los movimientos reformadores y a las actitudes reaccionarias, dos corrientes cuya interacción crea un epicentro en el cual hallamos, una vez más, a Verena.

\section{La Verena "vacía": la querella por el control de la voz en Las Bostonianas}

La lectura del personaje de Verena propuesta aquí nace de la fascinación por la atracción que la joven suscita en casi todos los personajes de la novela. Si nos ceñimos a las palabras del narrador de la historia, el gran don de Verena, aquello que la hace tan especial, es su elocuencia, su capacidad para hipnotizar y convertir con su voz al mayor de los incrédulos. Sin embargo, aquí cabe destacar un pequeño matiz, esto es, no son sus palabras las que ejercen tal poder, sino su tono hechizante. En su primera intervención en casa de Miss Birdseye, Ransom se da cuenta de que "the whole audience - Mrs. Farrinder, Miss Chancellor, and the tough subject from Mississippi were under the charm". No obstante, "[i]t was not what she said; he didn't care for that, he scarcely understood it; he could only see that it was all about the gentleness and goodness of women, and how, during the long ages of history, they had been trampled under the iron heel of man" (James, 2000: 56). Para Ransom, la imagen de la dama bella, débil e indefensa es la que suscita mayor atracción. Así, llega a la conclusión de que "the necessity of her nature was not to make converts to a ridiculous cause, but to emit those charming notes of her voice, to stand in those free young attitudes, to shake her braided locks like a naiad rising from the waves, to please everyone who came near her, and to be happy that she pleased" (57; la cursiva es mía). En esta misma línea, y tal y como menciona el narrador a continuación, las implicaciones de la teoría de Ransom son devastadoras para Verena, ya que proyectan una imagen vacía de lo extraordinario, una mera tabula rasa en la cual se inscriben las corrientes de deseo del resto de personajes. Como argumenta Scheiber, tanto Ransom como Olive ven en Verena la personificación de una causa, "and look to her as the human signifier through which their beliefs will be represented and actualized" (Scheiber, 1992: 236; la cursiva es mía). Desde esta perspectiva, el combate dialéctico entre Ransom y Olive se centra en el control de la voz de Verena, ya sea para utilizarla en pos de una causa o bien para silenciarla (Wolk, 1989: 50). Según Merla Wolk, la dinámica de la novela tiene su epicentro en la explotación y el dominio sucesivos de Verena por parte de sus padres, de Olive y de Ransom. De este modo, el potencial de Verena como fuerza subversiva se desvanece en un torbellino de discursos enfrentados que amenaza con 
desestabilizarla. Llegados a este punto, corresponde aludir a la singularidad de este personaje en el marco de la literatura del siglo diecinueve. La voz de Verena, a diferencia de la de muchas otras heroínas "coetáneas", es escuchada. No obstante, sus palabras, precisamente por los motives mencionados anteriormente, carecen de expresión interior; a través de ella solo accedemos al resto de personajes, nunca a la propia Verena, cuyo sentido del ser, su identidad, está supeditado a las voluntades ajenas.

Antes de analizar cada una de las corrientes de deseo que giran alrededor y dan cuerpo al personaje de Verena, es preciso definir a qué nos referimos cuando hablamos de deseo. El sentido más habitual de la palabra nos llevaría a concebir la relación entre Verena, Ransom y Olive dentro del marco del clásico triángulo amoroso, siendo esta la perspectiva adoptada por muchos críticos, cuyos trabajos se han centrado en el análisis de las inclinaciones afectivas de la joven e inocente Verena. ${ }^{4}$ No obstante, como se ha sugerido hasta ahora, las relaciones entre estos personajes van más allá de lo pasional. En la novela de James, el deseo se constituye como una fuerza que nace del Uno y se desplaza hacia el Otro, moldeando ambos entes y constituyendo, al mismo tiempo, una fuerza bidireccional que incide en su identidad. En palabras de Marta Segarra (2008: 7): “Nous entendons ici le mot 'désir' dans un sens étendu, se référant non seulement à l'amour et à la sexualité, mais aussi à d'autres formes d'expansion du 'moi' vers l'Autre, telle que l'écriture elle-même". Igualmente, "si nous l'entendons dans ce sens de tensions qui nous porte vers l'Autre, le désir est un thème fondamental dans toutes les manifestations artistiques, en tant qu'élément configurateur de l'identité individuelle" (179). El ejemplo de la escritura enlaza a la perfección en nuestro análisis de la obra, en cuanto que "The Bostonians is a war of significance in which Verena is treated as a blank page on which Ransom and Olive inscribe their competing desires" (Scheiber, 1992: 235; la cursiva es mía).

Una vez aclarado el sentido del deseo en la obra de James, veamos en qué consisten las fuerzas que dan cuerpo a Verena. En primer lugar, ya hemos examinado los aspectos de la joven que la hacen particularmente atractiva a los ojos de Basil Ransom. Este es presentado, desde un buen inicio, como un "caballero sureño". De este modo, sus valores son definidos como "caballerescos", determinando de una manera muy concreta su visión de la mujer y de lo femenino. Para Ransom, Verena personifica las cualidades ideales de la damisela en apuros apresada bajo las garras de la pérfida Olive:

\footnotetext{
${ }^{4}$ Asimismo, la adaptación cinematográfica llevada a cabo por James Ivory (1984) enfatiza el componente erótico presente en la relación de estos tres personajes, añadiendo escenas y actitudes - en comparación con la novela- que muestran al espectador aquello que el texto no explicita.
} 
He was addicted with the ladies to the old forms of address and of gallantry; he held that they were delicate, agreeable creatures, whom Providence had placed under the protection of the bearded sex; and it was not merely a humorous idea with him that whatever might be the defects of Southern gentlemen, they were at any rate remarkable for their chivalry. (James, 2000: 184; la cursiva es mía)

En este sentido, el ideal femenino de Ransom encaja a la perfección con el arquetipo del angel in the house, propio de la sociedad y de la cultura decimonónica, y según el cual toda mujer, ya sea en el rol de esposa o de madre, debía mostrarse como un paradigma de virtud y pureza; unos valores que presuponían su docilidad y modestia, así como una débil personalidad y sumisión a las expectativas masculinas, cuya inmediata consecuencia era la completa absorción y dominio de la mujer por parte del hombre. De este modo, toda mujer debía estar preparada y dispuesta a sacrificar, como es el caso de Verena, "their identity in deference to everyone in sight, and to seek their happiness 'only in the happiness of others"' (Dijkstra, 1986: 31). Verena puede llegar a ser obediente y sumisa en su voluntad de complacer a los demás. Sin embargo, dista mucho de controlar sus palabras. Es precisamente este aspecto de Verena el que Ransom quiere silenciar. Como él mismo declara: "[y]ou won't sing in the Music Hall, but you will sing to me; you will to every one who knows you and approaches you. Your gift is indestructible; don't talk as if I either wanted to wipe it out [...]. I want to give it another direction" (James, 2000: 376; la cursiva es mía). Dicho de otro modo, Verena tiene el potencial para abandonar el reino de lo privado y adentrarse en el de lo público; esto es percibido por Ransom como una amenaza a los valores tradicionales de la sociedad estadounidense: "Ransom's objection to Verena's singing her song in public is not motivated by merely personal interest; it is symptomatic of his fear of those 'feminine values', previously cloistered in the private domain, asserting themselves and leaving their mark on the 'public' world reserved for masculine beings like himself” (Scheiber, 1992: 239). Siguiendo esta misma línea de discusión, cabe considerar el trasfondo del interés de Ransom por Verena. Después de la Guerra Civil, un Sur derrotado y arrasado es percibido, en el imaginario colectivo, como "feminizado" ante un Norte victorioso. Esta noción, situada en un contexto más amplio - esto es, el de la cultura del éxito tan característica de la sociedad norteamericana-, implica una redefinición de la masculinidad del hombre sureño. Desde este punto de vista, Ransom siente que su masculinidad está desgajada, incompleta, aunque no está dispuesto a aceptar una reformulación de la misma. Ex combatiente de la Guerra Civil (1861-1865), antes que rendirse, decide probar suerte en el Norte, donde cree que sus posibilidades serán mayores. Así, alentado por el fantasma del fracaso, Ransom se aferra a Verena como a un clavo ardiente, viendo en ella su última oportunidad de realizarse. Sin embargo, como se nos relata al inicio del segundo 
libro, las cosas no le van muy bien en Nueva York: "Basil Ransom lived in New York, rather far to the eastward, and in the upper reaches of the town; he occupied two small shabby rooms in a somewhat decayed mansion which stood next to the corner of the Second Avenue" (James, 2000: 176; la cursiva es mía). No es solo el lugar que habita, sino que sus negocios tampoco marchan todo lo bien que deberían. En este estado de desesperación, Ransom sabe, gracias a Mrs. Luna, la hermana de Olive, del éxito de Verena, cuya reputación va en aumento. Él, en cambio, está ávido de triunfo. En palabras de Judith Wilt (1987: 300-301): “The 'gnawing hunger in his heart' is to shine in 'the haunts of men' (chap. 2) after confinement in the degraded, feminized South; meeting the piquant Verena stirs 'his starved senses' (chap. 8) [...]. He wants to drink her beauty and her improvisatory spontaneity and, most of all, her success". Desde esta perspectiva, hasta que Ransom no encuentra una voz pública, "he is unable to take advantage of the influence he has begun to have over her" (Wolk, 1989: 53). En el ideal de Ransom, nunca cabría la posibilidad de que Verena lo mantuviera en casa, siendo este uno de los motivos que lo llevan a rechazar la propuesta de Mrs. Luna, para quien el dinero no es ningún problema. Tal y como apunta Judith Fetterley, la amenaza que Ransom ve en Verena no solo reside en la desarticulación de las esferas de lo privado y de lo público, sino especialmente en el potencial subversivo de la joven para sobrevivir fuera del espacio que le es propio, fuera del hogar. Para Ransom, el dinero es poder, hecho que hace inconcebible la independencia económica de Verena y de Mrs. Luna. Así, "[t]he acceptance of his article for publication is [...] the turning point in Ransom's courtship of Verena: it is symbolic of his having regained control over what he sees as legitimately male territory; and it is therefore symbolic of his inevitable dominion over her and her inevitable capitulation to him" (Fetterley, 1978: 120121). Con todo, la cruzada de Ransom es concebida como la reconquista del espacio público; un espacio de articulación de lo político, cuya pérdida definitiva supondría la desestabilización de los cimientos fundadores de la sociedad patriarcal.

Además, y como se ha dicho con anterioridad, Ransom no es el único que persigue el potencial de Verena. Son sus padres quienes se aprovechan, en primera instancia, de las habilidades de su hija. Para el padre, Selah Tarrant, Verena significa la posibilidad de ganar dinero y obtener la fama que le daría notoriedad; su máxima aspiración es devenir un personaje público. Con la creciente fama de Verena, Selah Tarrant ve el éxito al alcance de la mano: por un lado, Olive les abona una suma importante de dinero a cambio de la tutela de la joven; por el otro, la participación de su hija en "la Causa" feminista atrae el interés de un sinfín de curiosos: "[s]uccess was not success so long as his daughter's physique, the rumour of her engagement, were not included in the 'Jottings' with the certainty of being extensively copied" (James, 2000: 97). Como ha señalado Merla Wolk (1989: 51), son los padres de Verena quienes establecen, en primer lugar, una pauta de dominación y de explotación de su propia hija. Un 
modelo que enseña a Verena, desde bien pequeña, a ser dependiente de los demás y a siempre estar dispuesta a complacer. Esta dependencia se evidencia en los discursos que realiza Verena junto a sus padres, donde " $[s]$ he has to have her father to start her up. It seems to pass into her" (49).

Asimismo, aunque con un rol secundario dentro de la novela, Mathias Pardon, portavoz de la prensa ${ }^{5}$ en el texto, también pretende a Verena. En su calidad de periodista, siempre está al acecho de cualquier noticia que pueda interesar a sus lectores. Mr. Pardon ve el potencial de Verena como celebrity, y esto lo lleva a buscar aliarse con ella: "For this ingenuous son of his age all distinction between the person and the artist had ceased to exist; the writer was personal, the person food for newsboys, and everything and everyone were every one's business" (James, 2000: 116). En último lugar, pero no por ello menos importante, cabe considerar la otra gran corriente de deseo, aparte de la de Basil, que se cierne sobre la figura de Verena. Olive Chancellor, a quien dedicaré mayor atención en el siguiente apartado, tiene una única gran pasión: conseguir la emancipación de las mujeres del yugo de los hombres. Aunque sus ideas al respecto son suficientemente sólidas, Olive carece de la habilidad para transmitirlas: "Olive, still not able to face the public herself, speaks through Verena, telling her what to say and where to say it" (Wolk, 1989: 52). El mayor defecto de Olive es su timidez: "Miss Olive Chancellor, it may be confided to the reader, $[\ldots]$ was subject to fits of tragic shyness, during which she was unable to meet even her own eyes in the mirror" (James, 2000: 7). Por estos motivos, Olive ve en Verena el medio a través del cual poder realizar su sueño. En consonancia con sus ideales, Olive proyecta, basándose en la amistad que las une, el deseo de evitar que ella sufra el mismo destino de muchas otras mujeres. Sin embargo, Olive intuye que Verena no está hecha para sufrir: "You were not made to suffer -you were made to enjoy" (280), vislumbrando, así, su porvenir.

Hasta ahora, el análisis llevado a cabo nos ha mostrado a una Verena cuya existencia como signo le confiere un potencial subversivo en cuanto a ente portador de significado. Sin embargo, este potencial resulta estéril, en tanto que la función de signo se impone sobre la función de sujeto, de modo que la libertad de Verena se ve coartada por deseos "otros", esto es, aquellos que provienen del resto de personajes. En este sentido, se crea una ausencia, un vacío llenado por las aspiraciones personales de cada uno de los miembros de la sociedad bostoniana. Tal y como afirma Elizabeth Allen (1984: 84), "The Bostonians is in part a final reduction of the way in which society manipulates and appropriates the female as sign, so that each and every active voracious individual can reinterpret and claim the American girl for his own". Tanto Olive como Basil ven

\footnotetext{
${ }^{5}$ La prensa es la fuerza vital en la publicitación de 'lo privado' en el XIX. Este tránsito de lo privado a lo público y sus consecuencias para la constitución de la identidad individual es otro de los temas subyacentes en la obra de James. Véase Bell (1990).
} 
en Verena el medio a través del cual su existencia "pública" puede llegar a realizarse; un medio que les facilitará su existencia social. Desde esta perspectiva, el principio femenino que representa Verena se reduce, una vez más, a la pasividad propia de la función de objeto, de modo que su inocencia se articula como ignorancia en relación a lo que le sucede: "[t]he woman as sign neither makes social existence meaningful, [...] nor comprehends her existence as sign in order to take control of the signifying process herself" (Allen, 1984: 95). La imposibilidad de comprender y de controlar el proceso de significación condena a la joven protagonista de James a un final trágico.

\section{Una lectura alegórica de la novela: la lucha por el dominio ideológico de las masas en la sociedad estadounidense de la posguerra}

El anterior apartado nos ha confirmado que la importancia de la Verena "ausente" y de las corrientes de deseo que se configuran a su alrededor es de primera magnitud en el desarrollo de la novela. De esta manera, en un intento de comprender estas dinámicas, el análisis llevado a cabo se ha centrado en las motivaciones personales de cada uno de los personajes en la lucha por el cuerpo de Verena. No obstante, la configuración del cuerpo femenino como espacio donde se inscriben deseos "otros" no se reduce a la esfera de lo privado, de lo personal, sino que trasciende a la esfera de lo público, de lo ideológico, de modo que es posible leer a cada uno de los personajes de la novela como el representante o bien de un conjunto de discursos, o bien de una clase social. En palabras de Catherine H. Zuckert (1976: 31), "all the characters in The Bostonians represent 'types'-Basil is 'representative of his sex' while Verena personifies 'the situation of women,' Olive, 'the agitation on their behalf,' and Mary Prance, 'the decline in the sentiment of sex"”. Así, este salto interpretativo nos ayudará a entender el elemento más característico de la novela, su ambigüedad, "[providing] a mean of contextualizing the novel's tensions and tonal shifts in ways that provide such readerly unease with some illuminating historical touchstones" (Ryan, 2005: 266).

En primer lugar, Verena no solo representa la situación de las mujeres, como argumenta Zuckert en la cita anterior, sino que su papel es mucho mayor: Verena simboliza la gran masa del pueblo norteamericano en sus primeros pasos, tras la guerra, como nación reunificada en el plano político, aunque disgregada en el ideológico. ${ }^{6}$ Llegados a este punto, la nación norteamericana necesita reconfigurar sus valores esenciales y no le faltan propuestas. En palabras de

\footnotetext{
${ }^{6}$ La configuración de la nación americana como principio femenino se remonta a los tiempos de los conquistadores, quienes proyectaron la visión de un continente puro y virgen aún por conquistar $y$, por lo tanto, esencialmente femenino. En este sentido, el personaje de Verena encarna, no de forma casual, estos valores fundacionales.
} 
Susan Ryan (2005: 267): "the narrative begins in the shadow of the Civil War, with two of its walking wounded, in psychological terms at least, gearing up for another sectional conflict, this time over the body and consciousness of an extraordinary young woman". Como se ha apuntado anteriormente, una de las faltas de la joven Verena, probablemente la más notoria, es su inocencia, hecho que la hace especialmente vulnerable a ser manipulada. Esto la lleva, en su deseo de complacer, a no distinguir entre una idea y otra, cayendo presa de sus padres, de Olive y de Basil de forma sucesiva: "[t]hough she had grown up among people who took for granted all sorts of queer laxities, she had kept the consummate innocence of the American girl, that innocence which was the greatest of all, for it had survived the abolition of walls and locks" (Zuckert, 1976: 115-116).

Por un lado, los valores progresistas norteños se encauzan en el movimiento por los derechos de la mujer, heredero del movimiento abolicionista y encabezado por Olive Chancellor. Como he apuntado en la introducción, James lanza una crítica contundente contra "la Causa", basada en la promoción de una imagen negativa de su principal portavoz, cuyos errores la condenan al fracaso. En primer lugar, "la Causa" se representa como un movimiento fragmentado, en el que las divergencias entre sus miembros resultan más que evidentes: Mrs. Farrinder, una de sus líderes, muestra su preferencia por la acción directa: "The coast was now perfectly clear. Mrs. Farrinder had started on her annual grand tour; she was rousing the people, from Maine to Texas" (James, 2000: 151). Por su parte, Olive prefiere el estudio de los libros de historia y el confort de su casa. En segundo lugar, la retórica del movimiento está teñida de una capa de moralidad que le imprime un tono piadoso poco convincente. De este modo, el léxico religioso abunda:

Olive Chancellor said to herself; she would do something to brighten the darkness of that dreadful image that was always before her, and against which it seemed to her at times that she had been born to lead a crusade - the image of the unhappiness of women. The unhappiness of women! The voice of their silent suffering was always in her ears, the ocean of tears that they had shed from the beginning of time seemed to pour through her own eyes. Ages of oppression had rolled over them; uncounted millions had lived only to be tortured, to be crucified. They were her sisters, they were her own, and the day of their delivery had dawned. This was the only sacred cause; this was the great, the just revolution. (33; la cursiva es mía)

La raíces puritanas del norte del país ejercen una considerable influencia en el imaginario colectivo, estructurando discursos y modos de pensamiento, tal y como sucede con Olive, cuya máxima principal es la pureza moral. Esta razón la lleva a concebir la moralidad como sacrificio, ensalzando, así, la idea del sufrimiento. Además, Olive concibe su leitmotiv como una cruzada sagrada, 
empleando una retórica que alude tangencialmente al pacto de los Puritanos con Dios para que estos descubrieran y poblaran "el Nuevo Israel", esto es, el continente americano (Bercovitch, 1974: 7). En tercer lugar, de la lectura de la novela se desprende la sensación de que Olive, aunque su mensaje es colectivo, adolece de cierto apego a la realidad de las bostonianas. Su extrema probidad moral la lleva a considerar "vulgares" (Zuckert 1976: 34) algunas de las actitudes mostradas tanto por sus compañeras militantes como por otras mujeres de la ciudad, creando cierta distancia y estableciendo jerarquías:

With her immense sympathy for reform, she found herself so often wishing that reformers were a little different. There was something grand about Mrs. Farrinder; it lifted one up to be with her: but there was a false note when she spoke to her young friend about the ladies in Beacon Street. Olive hated to hear that fine avenue talked about as if it were such a remarkable place, and to live there were a proof of worldly glory. All sorts of inferior people lived there, and so brilliant a woman as Mrs. Farrinder, who lived at Roxbury, ought not to mix things up. (James, 2000: 34)

Finalmente, Olive muestra una actitud agresiva, y recelosa en exceso, hacia los hombres, incluso hacia aquellos que muestran simpatía por "la Causa". En varias ocasiones, sus discursos parecen estar más encaminados hacia a la imposición de un matriarcado, esto es, más cerca de la creación de un nuevo orden de desigualdad. En este sentido, el problema de Verena es que "she does not 'dislike men as a class'” (Scheiber, 1992: 241).

Por otro lado, Ransom deviene el gran oponente de las ideas reformistas y la otra gran potencia opositora en la batalla por Verena. Sus principios son descritos como reaccionarios y conservadores, concibiendo todo tipo de reforma como una abominación, en cuanto amenaza al orden establecido: "Ransom has only contempt for the advancing 'democracy' of American life and construes the emancipation of blacks and of women alike as but symptoms of an evil 'progress' that is itself a perverse affront to nature" (Scheiber, 1992: 240). Además, Ransom considera que la Guerra Civil se originó en estos movimientos reformadores, añadiendo una razón más a su ya consolidado desagrado: "He is rather a 'realist' who opposes all dreams of human improvement because these idealistic 'illusions' merely give rise to more suffering" (Zuckert, 1976: 39). Del mismo modo, Ransom es, al igual que muchos otros personajes de la novela, una persona para quien la observación de la realidad pasa forzosamente por la acción de una serie de filtros que corresponden a una concepción fija de las cosas; para él, el concepto de "naturaleza" es inamovible. Esta rigidez a la hora de percibir el mundo le lleva a clasificar a la gente a través de estereotipos idealizados, cada uno encerrado en su cajón para evitar una posible contaminación. Basil es incapaz de ver más allá de estos constructos, que él acepta como naturales, relegando a 
Verena a la pasividad del ideal del angel in the house. No obstante, Ransom no es el único que peca de no querer ver más allá de los filtros; todos los personajes inscriben su ideología en Verena, acumulando una serie de capas discursivas que sepultan a la protagonista en la oscuridad más profunda del texto; una oscuridad sin retorno. Todas las alternativas, aduce James, son negativas, ya que representan "inadequate conceptions of human relations because [they] abstract from particular characteristics of individuals" (Zuckert, 1976: 39-40).

Desde esta perspectiva, muchos críticos y lectores han tendido a interpretar el final de la novela como el triunfo de los valores conservadores y, por lo tanto, han querido ver a James como defensor de los mismos. Sin embargo, nada podría estar más lejos de la realidad. Mientras que la crítica al movimiento reformista es bastante explícita dentro de la novela, el neoconservadurismo de Ransom tampoco resulta, como ha quedado demostrado, muy beneficiado. Además, James es bastante explícito en sus últimas líneas respecto al futuro infeliz que le aguarda a Verena: "But though she was glad, he presently discovered that, beneath her hood, she was in tears. It is to be feared that with the union, so far from brilliant, into which she was about to enter, these were not the last she was destined to shed" (James, 2000: 435). Aunque ninguna de las dos opciones es óptima, el tradicionalismo de Ransom lo lleva a "ver" la "naturaleza" de la joven, es decir, Ransom hace revivir en Verena la imagen interiorizada que sus padres y la sociedad le han estado inculcando desde pequeña. La opción de ser algo distinto, de desviarse del camino establecido, es una opción que Verena, en última instancia, no aprende de su experiencia con Olive. Olive le ofrece una alternativa, aunque $-\mathrm{y}$ aquí radica el error - impuesta, sin posibilidad de elección ni libertad y teñida de sacrificio. De este modo, Ransom disfraza la voluntad de complacer a los demás como el destino biológico de Verena (Scheiber, 1992: 242), escondiendo su cualidad de constructo ideológico: "It told him that she was afraid of him, that she had ceased to trust herself, that the way he had read her nature was the right way (she was tremendously open to attack, she was meant for love, she was meant for him)" (James, 2000: 352; la cursiva es mía). La estrategia de Ransom consiste en desenmascarar a su adversaria, en mostrarle a Verena la manipulación a la que ha estado sometida desde bien pequeña, primero por sus padres y luego por Olive. De este modo, apela a la libertad de Verena, presentando su propuesta, su forma de ver las cosas, como la correcta: "how much you might please someone else by tipping your preposterous puppet over and standing forth in your freedom as well as in your loveliness" (325-326). Al fin y al cabo, Ransom representa la seguridad propia de la tradición y del orden establecido, mientras que los valores de Olive exhiben la inestabilidad e incerteza propias de la novedad, del cambio. Finalmente, el "pequeño" ardid de Ransom es lo que hace inclinar la balanza; Verena, bajo el velo de la ilusión y la inocencia, se deja engañar por sus artimañas, reconociendo en ellas verdades absolutas. Como afirma Scheiber (1992: 244), “[w] hat is at stake in The Bostonians is whether human beings - and in particular women- dare 
hope for, dare aspire toward, a place in the world beyond what custom and common usage have assigned them".

\section{Conclusión}

Los dos niveles de lectura llevados a cabo en las secciones precedentes nos han ayudado a leer la novela de James como una crítica a la sociedad estadounidense de la época, sobrepasando, de este modo, las interpretaciones reduccionistas del texto. El primer apartado nos ha llevado a entender, partiendo de la concepción del cuerpo femenino como signo, las particularidades del personaje principal de la historia, Verena Tarrant, y las dinámicas de deseo que le dan cuerpo. A continuación, el segundo apartado nos ha permitido hacer un salto interpretativo para así poder leer dichas dinámicas desde una óptica alegórica, situando la novela en su debido contexto histórico e ideológico. De este modo, las ambigüedades inherentes que presenta el texto, y que a la vez constituyen su mayor riqueza, han quedado parcialmente resueltas. Al final de este proceso, James nos ofrece el retrato de una sociedad ideológicamente perdida, desorientada. El dibujo, lejos de las visiones utópicas de Olive y Basil, nos muestra una alarmante distopía: "[b]y placing his heroine between two unacceptable alternatives, James thus suggests that no utopian scheme can ever succeed and that Verena (America) is in for a hard life" (Martin, 1985: 110). Las alternativas no resultan aceptables porque ambas acogen valores caducos que ignoran las nuevas realidades de la nación, esto es, Verena. Como señala el final de la novela, la unión entre norte y sur, realizada a través de la violencia, no puede generar sino más sufrimiento. En palabras de Susan Ryan (2005: 270): "The Bostonians does not end in celebration, as do conventional romance-ofreunion narratives, where the happy resolution of the love plot signals the return of national unity and an easing of the South's economic hardships". En suma, Las Bostonianas deviene una sátira social cuya principal reflexión contiene una advertencia sobre el peligro de la ingenuidad y de una sociedad cegada por sus mitos, susceptible a ellos y, por ende, fácilmente manipulable. La querella por la voz de Verena se convierte, al final del día, en la lucha por el control ideológico de las masas. En un nivel más personal, donde están en juego las relaciones entre individuos, el final viene a confirmar la "ausencia" de Verena y su condición de objeto dentro de la sociedad. El intercambio se ha producido, de las manos de su padre en su primera aparición - manos sin las cuales Verena no puede empezar sus intervenciones - a las de Ransom, quien, casi a la fuerza, la arrastra a una vida anónima y desoladora.

\section{REFERENCIAS BIBLIOGRÁFICAS}

Allen, Elizabeth (1984), A Woman's Place in the Novels of Henry James, Londres, MacMillan Press. 
Bell, Ian F.A. (1990), "The Personal, the Private, and the Public in The Bostonians", Texas Studies in Literature and Language, 32.2: 240-256.

Bercovitch, Sacvan (1974), "Introduction", The American Puritan Imagination: Essays in Revaluation, Sacvan Bercovitch (ed.), Nueva York, Cambridge UP: 1-16.

Dijkstra, Bram (1986), Idols of Perversity: Fantasies of Feminine Evil in Fin-deSiècle Culture, Nueva York, Oxford UP.

Fetterley, Judith (1978), The Resisting Reader: a Feminist Approach to American Fiction, Bloomington, Indiana UP.

James, Henry (2000), The Bostonians, Nueva York, Oxford UP.

Martin, Robert K. (1985), “The Bostonians: James's Dystopian View of Social Reform", Mosaic, 18.1: 107-113.

Ryan, Susan M. (2005), "The Bostonians and the Civil War", The Henry James Review, 26.3: 265-272.

Scheiber, Andrew J. (1992), "Eros, Art, and Ideology in The Bostonians", The Henry James Review, 13: 235-52.

Segarra, Marta (2008), Le Désir et ses interprétations, París, L'improviste.

Wilt, Judith (1987), "Desperately Seeking Verena: A Resistant Reading of The Bostonians", Feminist Studies, 13.2: 293-316.

Wolk, Merla (1989), "Family Plot in The Bostonians: Silencing the Artist's Voice", The Henry James Review, 10.1: 50-59.

Zuckert, Catherine H. (1976), "American Women and Democratic Morals: The Bostonians”, Feminist Studies, 3.3/4: 30-50. 